\title{
Ruptured Intracranial Dermoid Cyst: About two cases
}

\author{
Zouine Y*, Essamadi M, S El Fakir, K Aniba, S Alj
}

Service de Radiologie Hôpital Ibn Tofail CHU Mohamed VI, Université Cadi Ayad Marrakech, Maroc

DOI: $10.36347 /$ sjmcr.2020.v08i09.001

| Received: 21.08.2020 | Accepted: 29.08.2020 | Published: 02.09.2020

*Corresponding author: Zouine $\mathrm{Y}$

Abstract

Case Report

Intracranial dermoid cysts are uncommon lesions. They account for $<1 \%$ of all intracranial masses, with characteristic imaging appearances, they are usually well-defined lobulated midline masses that have low attenuation (fat density) on computed tomography CT and high signal intensity on T1-weighted the magnetic resonance imaging (MRI). Typically they do not enhance after contrast administration. Rupture of intracranial dermoid cysts (RICDC) is a rare phenomenon and in this article we report two additional cases to the literature. The rupture can be traumatic or nontraumatic and CT is often adequate in making a diagnosis of this entity, MRI can complete the characterization showing presence of T1 hyperintense droplets and leptomeningeal enhancement. This complication can be treated surgically or conservatively depending on the clinical symptoms.

Keywords: Ruptured Dermoid cysts.

Copyright @ 2020: This is an open-access article distributed under the terms of the Creative Commons Attribution license which permits unrestricted use, distribution, and reproduction in any medium for non-commercial use (NonCommercial, or CC-BY-NC) provided the original author and source are credited.

\section{INTRODUCTION}

The intracranial dermois cyst (DC) is a rare entity, accounting for $0.1-0.7 \%$ of all intracranial tumors $[1,2,3]$. Its frequency is $4-10$ times lower than epidermoid cysts [2]. They are benign, slow-growing congenital neoplasms and are believed to arise from ectopic ectodermal cell rests incorporated in the neural groove at the time of closure. [4,5]. Rupture of intracranial dermoid cysts (RICDC) is a rare phenomenon and in this article we report two additional cases to the literature.

\section{Case Report}

Case 1

A 40-year-old patient with no particular pathological history, who had a sudden decrease in visual acuity followed by a loss of consciousness in the context of apyrexia. The clinical examination found multiple dermatological lesions made of nodular lesions under the cutaneous scalp without any other associated abnormality. An enhanced cerebral CT scan was performed (Figure 1) and showed a calcified suprasellar cystic lesion with heterogeneous density and containing fat and fluid component with fat droplets in the subarachnoid spaces. The patient underwent surgery evolution was characterized by the disappearance of headaches with stability of visual acuity.

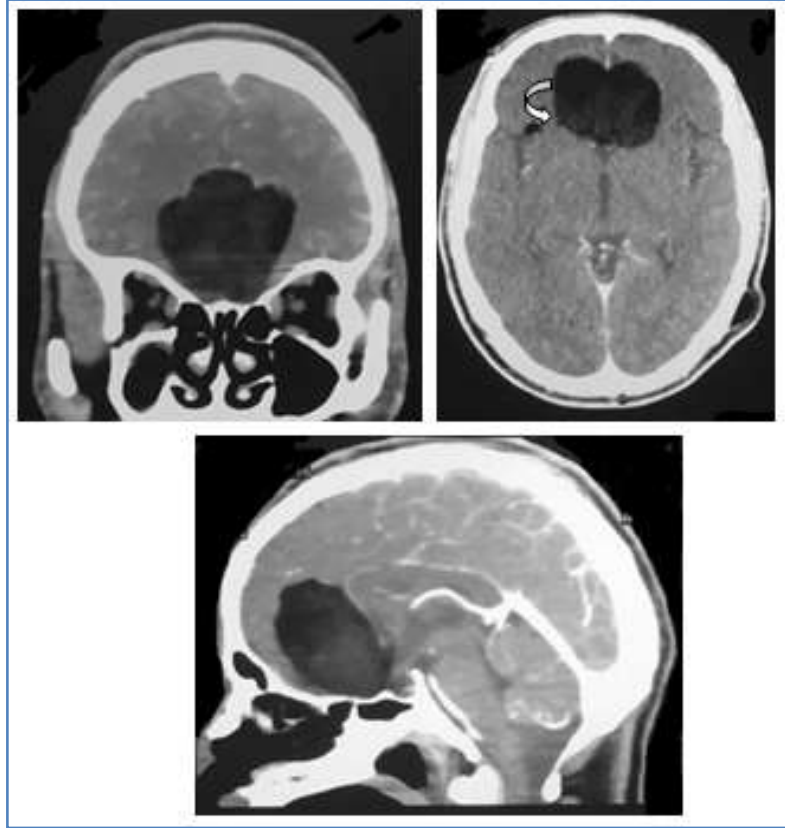

Fig-1: enhanced CT scan showing dermoid cyst of the suprasellar region ruptured in subarachnoid spaces. Note the presence of fat droplets (arrow) in the subarachnoid spaces

Case 2

A 52 year old woman came to the ER with a sudden-onset headache, left-sided weakness and generalized tonic clonic seizures. There was no past medical history or drug use. An unenhanced CT of the head showed a large low-attenuation lesion in her right 
fronto-temporal lobe with calcified borders, there was an additional low-attenuation droplet in the subarachnoid space layering in the basal cisterns and cerebellar sulci, consistent with rupture (figure 2). The evolution was fatal in this case.
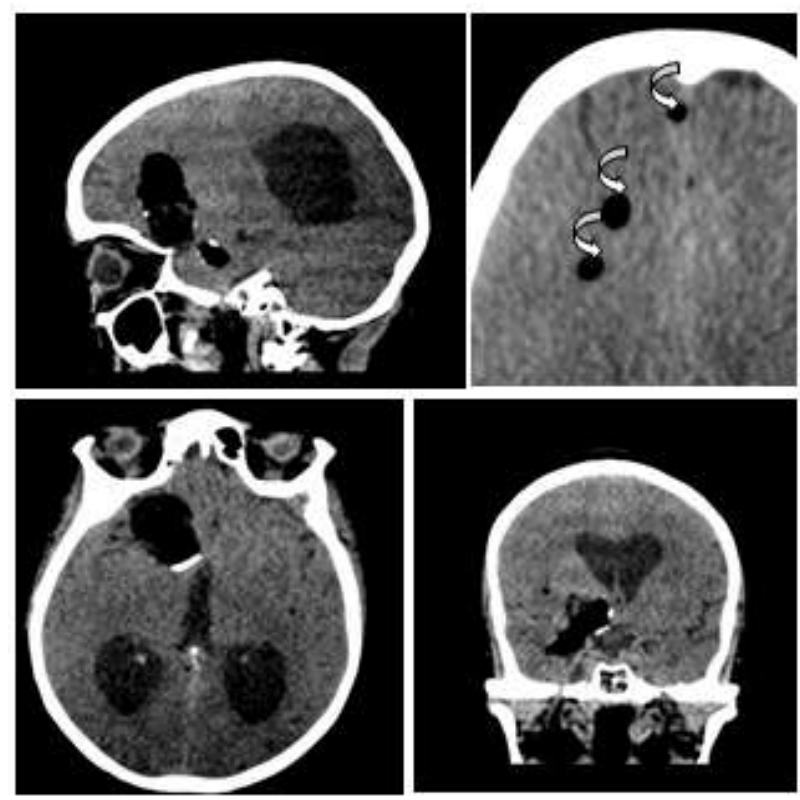

Fig-2: Anenhanced CT scans showing a solid fat density lesion in the frontotemporal lobe with multiple locules of fat (arrows), suggesting cyst rupture

\section{DISCUSSION}

The intracranial dermois cyst (DC) is a rare entity, accounting for $0.1-0.7 \%$ of all intracranial tumors [1-3]. Its frequency is $4-10$ times lower than epidermoid cysts [2].

They are benign, slow-growing congenital neoplasms and are believed to arise from ectopic ectodermal cell rests incorporated in the neural groove at the time of closure $[4,5]$.

The median line, the posterior cerebral fossa and the spinal cord are the preferred seats of DC [6, 7] Suprasellar dermoid cysts (SDC) are exceptional and can compress the chiasma, pituitary stalk, and hypothalamus.

Rupture of an intracranial dermoid cyst, although rare, occurs mostly spontaneously but may be iatrogenic during surgery or after closed head injury [8, 9]. Spontaneous rupture of SDC is correlated with cyst size and results in heterogeneous fatty material in subarachnoid spaces and aseptic chemical meningitis [10]. Symptoms are insidious and non-specific, commonly due to local mass effect resulting in focal neurological dysfunction or obstruction of the cerebrospinal fluid pathway. Clinical features depend on their location, seizure and headache being the most common with uncomplicated supratentorial dermoid cysts. [11].
Imaging findings vary, depending on whether the cyst has ruptured [12]. On CT scans, dermoid cysts can have mixed densities, and rarely enhance following contrast administration [13-16]. The intracystic fat and disseminated fat droplets appears hypodense, whereas calcifications in the wall are hyperdense. Hydrocephalus and fat-fluid level may be present following rupture into the ventricular system. On MRI, dermoid cysts are hyperintense on T1-weighted sequences and variable on T2-weighted sequences, although the presence of cholesterol can often make them appear hypointense on T2 as well [12, 16-18]. Dermoid cysts can be differentiated from epidermoid cysts in that the former demonstrates fat signal on CT and MRI whereas the latter resembles CSF [19-21]. Differentiating a dermoid cyst from craniopharyngiomas is relatively easier, as the latter enhances strongly on CT $[22,23]$. In addition, the craniopharyngioma cyst walls also display strong enhancement on T1-weighted MRI sequences [24, 25]. Teratomas help distinguish themselves via their calcifications, which are hyperintense on CT [26, 27].

Computed tomography is the initial imaging method used in emergency departments [28], but The capability of MR to evaluate the associated vessel displacement, either by flow void or MR angiography, paired with better visualization of the lesions relative to the base of the skull owing to lack of bone interference and multiplanar imaging capability, make MR the preferred preoperative imaging method [29].

Ruptured intracranial dermoid cysts in general require surgical removal with extensive rinsing of the subarachnoid space during the surgery [30]. Conservative treatment may be considered for broken cysts where there is a risk of intraoperative vascular involvement, but with a risk of recurrence of rupture [31]. In the absence of surgical treatment, regular monitoring by MRI is strongly recommended, in order to follow the evolution of the extent of the spread of lipid droplets and to detect a possible aggravation, and to detect a possible recurrence in the framework of the postoperative follow-up [32].

\section{REFFERENCE}

1. Guidetti B, Gagliardi FM. Epidermoid and dermoid cysts: clinical evaluation and late surgical results. Journal of neurosurgery. 1977 Jul 1;47(1):12-8.

2. Hinojosa M, Tatagiba M, Harada K, Samii M. Dermoid cyst in the posterior fossa accompanied by Klippel-Feil syndrome. Child's Nervous System. 2001 Jan 1;17(1-2):97-100.

3. Lunardi P, Missori P, Gagliardi FM, Fortuna A. Dermoid cysts of the posterior cranial fossa in children. Report of nine cases and review of the literature. Surgical neurology. 1990 Jul 1;34(1):3942. 
4. Stendel R, Pietilä TA, Lehmann K, Kurth R, Suess O, Brock M. Ruptured intracranial dermoid cysts. Surgical neurology. 2002 Jun 1;57(6):391-8.

5. Lavi E, Goldberg HI. Extra axial brain tumors. In: Atlas AW, eds. Magnetic resonance imaging of the brain and spine, 3rd edn. Philadelphia: Lippincott Williams \& Wilkins. 2002:695-772.

6. COBBS CS, Pitts LH, Wilson CB. Epidermoid and dermoid cyst of the posterior fossa. Clin Neurosurg. 1997; 44: 511-528.

7. HIGASHI S, TAKINAMI K, YAMASHITA J. Occipital dermal sinus associated with dermoid cyst in the fourth ventricle. Am J Neuroradiol. 1995;16: 945-948.

8. Phillips WE II, Martinez CR, Cahill DW. Ruptured intracranial dermoid tumor secondary to closed head trauma. Computed tomography and magnetic resonance imaging. J Neuroimaging. 1994;4:16970.

9. Carvalho GA, Cervio A, Matthies C, Samii M. Subarachnoid fat dissemination after resection of a cerebellopontine angle dysontogenic cyst: case report and review of the literature. Neurosurgery. 2000 Sep 1;47(3):760-4.

10. Dietemann JL. Neuro-imagerie diagnostique. Elsevier Health Sciences; 2018 Jun 26.

11. Lunardi P, Missori P. Supratentorial dermoid cysts. J Neurosurg. 1991;75:262-6.

12. Osborn AG, Preece MT. Intracranial cysts: radiologic- pathologic correlation and imaging approach. Radiology. 2006; 239(3): 650-64.

13. Stephenson TF, Spitzer RM. MR and CT appearance of ruptured intracranial dermoid tumors. Comput Radiol. 1987; 11(5-6):249-51.

14. Hamer J. Diagnosis by computerized tomography of intradural dermoide with spontaneous rupture of the cyst. Acta Neurochir (Wien). 1980; 51(3-4): 219-26.

15. Jamjoom AB, Cummins BH. The diagnosis of ruptured intracranial dermoid cysts. $\mathrm{Br} \mathrm{J}$ Neurosurg. 1989; 3(5): 609-12.

16. Davidson HD, Ouchi T, Steiner RE. NMR imaging of congenital intracranial germinal layer neoplasms. Neuroradiology. 1985; 27(4): 301- 3.

17. Chen S, Ikawa F, Kurisu K, Arita K, Takaba J, Kanou Y. Quantitative MR evaluation of intracranial epidermoid tumors by fast fluidattenuated inversion recovery imaging and echoplanar diffusion-weighted imaging. AJNR Am J Neuroradiol. 2001; 22(6): 1089-96.

18. Dutt SN, Mirza S, Chavda SV, Irving RM. Radiologic differentiation of intracranial epidermoids from arachnoid cysts. Otol Neurotol. 2002; 23(1): 84-92.

19. Smith AS, Benson JE, Blaser SI, Mizushima A, Tarr RW, Bellon EM. Diagnosis of ruptured intracranial dermoid cyst: value MR over CT. AJNR Am J Neuroradiol. 1991; 12(1): 175-180.

20. Orakcioglu B, Halatsch ME, Fortunati M, Unterberg A, Yonekawa Y. Intracranial dermoid cysts: variations of radiological and clinical features. Acta Neurochir (Wien). 2008; 150(12): 1227-34.

21. Schaefer PW, Grant PE, Gonzalez RG. Diffusionweighted MR imaging of the brain. Radiology. 2000 Nov; 217(2): 331-45.

22. Tsuruda JS, Chew WM, Moseley ME, Norman D. Diffusion-weighted MR imaging of the brain: value of Liang L, Korogi Y, Sugahara T, Ikushima I, Shigematsu Y, Okuda T. MRI of intracranial germcell tumours. Neuroradiology. 2002; 44(5): 382-8.

23. Sandow BA, Dory CE, Aguiar MA, Abuhamad AZ. Best cases from the AFIP: congenital intracranial teratoma. Radiographics: a review publication of the Radiological Society of North America, Inc. 24(4): 1165- 70.

24. Larsson EM, Brandt L, Holtas S. Persisting intraventricular fat-fluid levels following surgery on a ruptured dermoid cyst of the posterior fossa. Acta Radiol. 1987; 28(4): 489-90.

25. Carvalho GA, Cervio A, Matthies C, Samii M. Subarachnoid fat dissemination after resection of a cerebellopontine angle dysontogenic cyst: case report and review of the literature. Neurosurgery. 2000; 47(3): 760-64.

26. Kaido T, Okazaki a, Kurokawa S, Tsukamoto M. Pathogenesis of intraparenchymal epidermoid cyst in the brain: a case report and review of the literature. Surg Neurol. 2003; 59(3): 211-6.

27. Iaconetta G, Carvalho GA, Vorkapic P, Samii M. Intracerebral epidermoid tumor: a case report and review of the literature. Surg Neurol. 2001; 55(4): 218-22.

28. Wani AA, Raswan US, Malik NK, Ramzan AU. Posterior fossa ruptured dermoid cyst presenting with hydrocephalus. Neurosciences (Riyadh). 2016;21:358-60

29. Sefedin M, Mehmet SU, Kreshnike D, Naser R, Naim J. Role of MRI in Diagnosis of Ruptured Intracranial Dermoid Cyst. ACTA INFORM MED. 2017 JUN; 25(2): 141-144.

30. Stendel R, Pietilä TA, Lehmann K, Kurth R, Suess O, Brock M. Ruptured intracranial dermoid cysts. Surgical neurology. 2002 Jun 1;57(6):391-8.

31. Park SK, Cho KG. Recurrent intracranial dermoid cyst after subtotal removal of traumatic rupture. Clin Neurol Neurosurg. 2012;114:421-424.

32. Borni M, Abdelhedi A, Kammoun B, Kolsi F, Boudawara MZ. Ruptured Central Nervous System Dermoid Cyst of Suprasellar Region Manifesting as Unusual Epileptic Seizure. World neurosurgery. 2019 Feb 1;122:150-4. 